\title{
A Unified Potentiostat for Electrochemical Glucose Sensors
}

\author{
Ki-Sung Sohn \\ Department of Electronic Engineering, Kyungnam University, Changwon 631-701, Korea
}

Seok-Jae Oh, Eui-Jin Kim, Jeong-Min Gim, Nam-Soo Kim, and Yeong-Seuk Kim ${ }^{+}$
Department of Semiconductor Engineering, Chungbuk National University, Cheongju 361-763, Korea

Jong-Won Kim

Department of Chemical Engineering, Chungbuk National University, Cheongju 361-763, Korea

Received January 14, 2013; Revised August 23, 2013; Accepted September 3, 2013

A unified potentiostat circuit for both $\mathrm{O}_{2}$ - and $\mathrm{H}_{2} \mathrm{O}_{2}$ - based electrochemical glucose sensors was proposed and its function was verified by circuit simulations and measurement results of a fabricated chip. This circuit consisted of an operational amplifier, a comparator and current mirrors. The proposed circuit was fabricated with a $0.13 \mu \mathrm{m}$ thick oxide CMOS process and an active area of $360 \mu \mathrm{m} \times 100 \mu \mathrm{m}$. The measurements revealed an input operation range from $0.5 \mathrm{~V}$ to $1.6 \mathrm{~V}$ in the $\mathrm{H}_{2} \mathrm{O}_{2}$ - based bio-sensor and from $1.7 \mathrm{~V}$ to $2.6 \mathrm{~V}$ in the $\mathrm{O}_{2}$ - based bio-sensor with a supply voltage of 3.3 V. The evaluation results showed that the proposed potentiostat circuit is suitable for measuring the electrochemical cell currents of both $\mathrm{O}_{2}$ - and $\mathrm{H}_{2} \mathrm{O}_{2}$ - based glucose sensors.

Keywords: Electrochemical cell, Glucose sensor, Potentiostat, Comparator, Current mirror

\section{INTRODUCTION}

Recently, the aging of the population has progressed rapidly with economic growth and the development of medical technology. Accordingly, the number of patients with chronic diseases, such as diabetes and cardiovascular diseases, has increased. As diabetes has high death rate, there is a strong need for portable measurement instruments that can diagnose diabetes easily.

Electrochemical sensors, optical sensors, piezoelectric sensors and acoustic sensors are used to measure the blood glucose for the diagnosis of diabetes [1]. Among them, the electrochemical sensor is used widely, because it is simple to manufacture with compact size and fast diagnosis.

${ }^{\dagger}$ Author to whom all correspondence should be addressed:

E-mail: andrewsohn@kaist.ac.kr

Copyright $@ 2013$ KIEEME. All rights reserved.

This is an open-access article distributed under the terms of the Creative Commons Attribution Non-Commercial
License (http://creativecommons.org/licenses/by-nc/3.0) which permits unrestricted noncommercial use License (http://creativecommons.org/licenses/by-nc/3.0) which permits unrestricted
distribution, and reproduction in any medium, provided the original work is properly cited.
An electrochemical glucose biosensor is based on the enzyme, glucose oxidase (GOD). This enzyme catalyzes the oxidation of glucose, which is a two step reaction process.

Two different types of electrochemical glucose biosensors are available on the market: an amperometric sensor and potentiometric sensor. The amperometric glucose sensor is based on measurements of electron flow during the oxidation or reduction, but the potentiometric sensor measures the potential changes in local $\mathrm{pH}$ during the reaction process. The amperometric glucose sensor is used most commonly due to its simple structure and low cost.

The amperometric electrochemical sensor consists of an electrochemical cell and a potentiostat, as shown in Fig. 1. The electrochemical cell consists of a working electrode (WE) onto which the reaction takes place, a reference electrode (RE) that maintains the constant potential, and a counter electrode (CE) that supplies the reaction current. The potentiostat supplies a desired cell potential $\mathrm{V}_{\text {cell }}$ between WE and RE, and measures the reaction current between the WE and CE [2]. 
Oxygen-electrode-based $\left(\mathrm{O}_{2}\right.$-based $)$ and hydrogen-peroxideelectrode-based $\left(\mathrm{H}_{2} \mathrm{O}_{2}\right.$-based) sensors are the two most widely used electrochemical glucose biosensors. In an $\mathrm{O}_{2}$-based glucose sensor, when the cell potential $\mathrm{V}_{\text {cell }}$ between $\mathrm{WE}$, made out of $\mathrm{Pt}$, and $\mathrm{RE}$, made out of $\mathrm{Ag} / \mathrm{AgCl}$, is typically $-600 \mathrm{mV}, \mathrm{WE}$ emits electrons into solution by the reduction of oxidation at the surface of WE. Therefore, the output current is flowing from the CE to WE.

In the $\mathrm{H}_{2} \mathrm{O}_{2}$-based glucose sensor, when $\mathrm{V}_{\text {cell }}$ is typically +700 $\mathrm{mV}, \mathrm{WE}$ absorbs electrons by the oxidation of hydrogen peroxide at the surface of WE. Therefore, the output current flows from the WE to CE [1].

Several configurations can be used to implement the potentiostat of an amperometric electrochemical sensor [3]. The method most commonly used is the use of a trans-impedance amplifier (TIA) that consists of two amplifiers. The first negative feedback amplifier is used to force $\mathrm{V}_{\text {cell }}$ to WE with reference to RE, and the second amplifier measures the current generated at WE. This circuit is simple and can measure low currents by increasing the feedback impedance. On the other hand, this technique requires the positive and negative input voltage to generate the current of both $\mathrm{O}_{2}$-based and $\mathrm{H}_{2} \mathrm{O}_{2}$-based sensor, because the direction of the current generated in the $\mathrm{O}_{2}$-based sensor is opposite to that of the current generated in the $\mathrm{H}_{2} \mathrm{O}_{2}$-based sensor

Other configurations to implement the potentiostat use a current conveyor [4-7]. This involves the insertion of a resistor in the current path at WE, where the voltage drop is measured. Another approach for the current measurement in the potentiostat is the use of a current mirror [3]. This technique is easy to design and requires few components. On the other hand, two types of potentiostats need to measure the current generated in the $\mathrm{O}_{2}$ based and $\mathrm{H}_{2} \mathrm{O}_{2}$-based sensors.

In this paper, a unified potentiostat circuit, which can measure the current of both $\mathrm{O}_{2}$-based and $\mathrm{H}_{2} \mathrm{O}_{2}$-based glucose sensors with one chip, was implemented using current mirrors. This potentiostat is very simple, has low power and a good measurement of current generated in both $\mathrm{O}_{2}$-based and $\mathrm{H}_{2} \mathrm{O}_{2}$-based glucose sensor.

This paper is composed of five sections. The potentiostat based on a current mirror is explained in section II and the circuit design of the proposed poentiostat is described in section III. The evaluation results of the fabricated chip are shown in section IV, and finally, the conclusions are reported in section V.

\section{CURRENT MIRROR BASED POTENTIOSTAT}

Figure 2 shows the current mirror-based potentiostat circuit for an $\mathrm{O}_{2}$-based glucose sensor.

The operational amplifier and MOSFET M1 were configured as a negative feedback loop through which the input voltage $\mathrm{V}_{\text {in }}=$ $+600 \mathrm{mV}$ was applied to the RE and WE is ground, then $\mathrm{V}_{\text {cell }}\left(\mathrm{V}_{\mathrm{WE}^{-}}\right.$ $\mathrm{V}_{\mathrm{RE}}$ ) is $-600 \mathrm{mV}$. Under these conditions, reaction current $\mathrm{I}_{\mathrm{F}}$ flows from $\mathrm{CE}$ to $\mathrm{WE}$ and is copied to $\mathrm{I}_{\mathrm{F} 1}$ by the current mirror, which consists of M1 and M2. The voltage drop was measured across $R_{M}$, which is proportional to the sensed current $I_{F}$ This potentiostat circuit cannot be used for the $\mathrm{H}_{2} \mathrm{O}_{2}$-based sensor, because of the opposite polarities of the cell potential and currents.

Figure 3 shows the potentiostat circuit for the $\mathrm{H}_{2} \mathrm{O}_{2}$-based sensor.

In this circuit, $\mathrm{V}_{\mathrm{in}}=\mathrm{VDD}-700 \mathrm{mV}$ was applied to the $\mathrm{RE}$ and $\mathrm{WE}$ is VDD respectively, then $\mathrm{V}_{\text {cell }}\left(\mathrm{V}_{\mathrm{WE}}-\mathrm{V}_{\mathrm{RE}}\right)$ is $+700 \mathrm{mV}$ and the reaction current flowed from the $\mathrm{WE}$ to $\mathrm{CE}$ and was measured by the current mirror, $\mathrm{M} 1$ and $\mathrm{M} 2$.

In current mirror typed potentiostat, two different potentio-

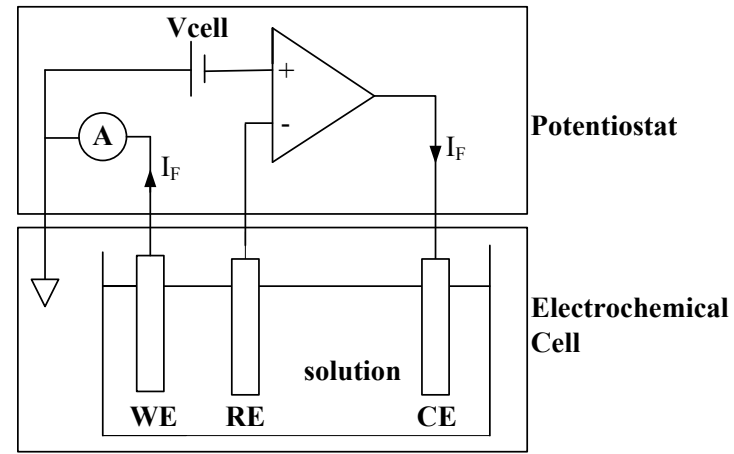

Fig. 1. Block diagram of an amperometric three electrode electrochemical cell and potentiostat.

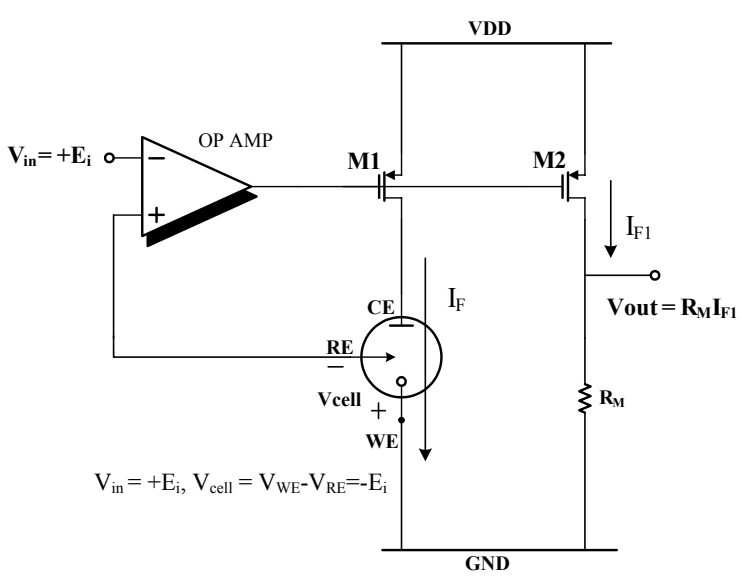

Fig. 2. Potentiostat for the $\mathrm{O}_{2}$-based glucose sensor using a current mirror.

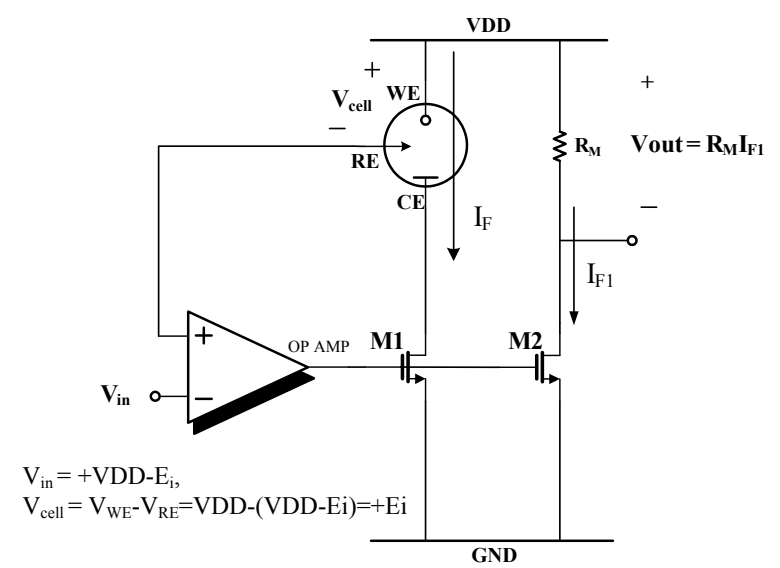

Fig. 3. Potentiostat circuit for the $\mathrm{H}_{2} \mathrm{O}_{2}$ - based glucose sensor using a current mirror.

stats are required to drive the $\mathrm{O}_{2}$ - based and $\mathrm{H}_{2} \mathrm{O}_{2}$ - based glucose sensor.

\section{CIRCUIT IMPLEMENTATION}

New potentiostat topology that can generate the cell potential of two different $\mathrm{O}_{2}$ and $\mathrm{H}_{2} \mathrm{O}_{2}$-based sensors using a current mir- 


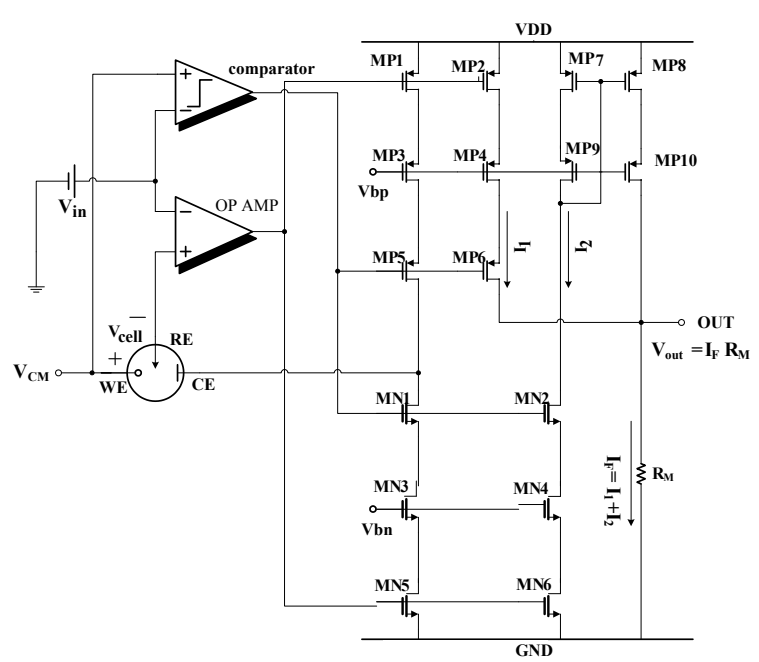

Fig. 4. Proposed integrated potentiostat topology for $\mathrm{O}_{2}$ and $\mathrm{H}_{2} \mathrm{O}_{2}$ based sensors.

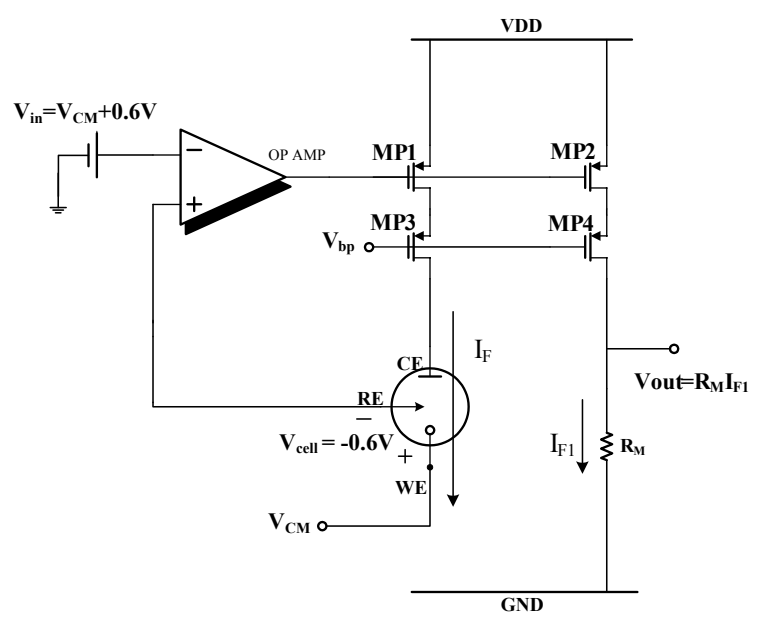

Fig. 5. Equivalent circuit of the proposed potentiostat for $\mathrm{O}_{2}$ based glucose sensor.

ror is described in this section. Figure 4 shows the proposed unified potentiostat that can manage opposite cell potentials and current flows in $\mathrm{O}_{2}$ and $\mathrm{H}_{2} \mathrm{O}_{2}$-based sensors.

The proposed potentiostat consists of a comparator, an operational amplifier and two cascode-type current mirrors. The voltage of $\mathrm{WE}\left(\mathrm{V}_{\mathrm{CM}}\right)$ was set to half of the power supply voltage (VDD/2) to obtain the maximum input dynamic range. The comparator checks the polarity of the cell potential, $\mathrm{V}_{\text {cell }}=\mathrm{V}_{\mathrm{WE}^{-}}$ $\mathrm{V}_{\mathrm{RE}}=\mathrm{V}_{\mathrm{CM}}-\mathrm{V}_{\mathrm{in}}$, and deactivates the unnecessary current mirrors. The operational amplifier with MOSFETs MP1 and MN5 forms a negative feedback loop that keeps the potential of RE to $V_{\text {in }}$.

Figure 5 shows the equivalent circuit of potentiostat for the $\mathrm{O}_{2}$-based sensor. In an $\mathrm{O}_{2}$-based glucose sensor, $\mathrm{V}_{\text {in }}$ is set to $\mathrm{VDD} / 2+600 \mathrm{mV}$ to get a negative $\mathrm{V}_{\text {cell }}(-600 \mathrm{mV})$ and the comparator output is low, because $\mathrm{V}_{\text {in }}>\mathrm{V}_{\mathrm{CM}}$. Therefore, PMOS MP5 and MP6 are on and the PMOS current mirror MP1-MP4 is activated, but NMOS MN1 and MN2 are off and the NMOS current mirror MN3-MN6 and PMOS current mirror MP7-MP10 are deactivated.

Figure 6 shows the equivalent circuit of the potentiostat for the $\mathrm{H}_{2} \mathrm{O}_{2}$-based sensor. In the $\mathrm{H}_{2} \mathrm{O}_{2}$-based sensor, $\mathrm{V}_{\text {in }}$ is set to $\mathrm{V}_{\mathrm{CM}^{-}}$ $\mathrm{V}_{\text {cell }}=\mathrm{VDD} / 2-700 \mathrm{mV}$ to have a positive cell potential $(+700 \mathrm{mV})$ and the comparator output is high, because $\mathrm{V}_{\mathrm{in}}<\mathrm{V}_{\mathrm{CM}}$. Therefore,

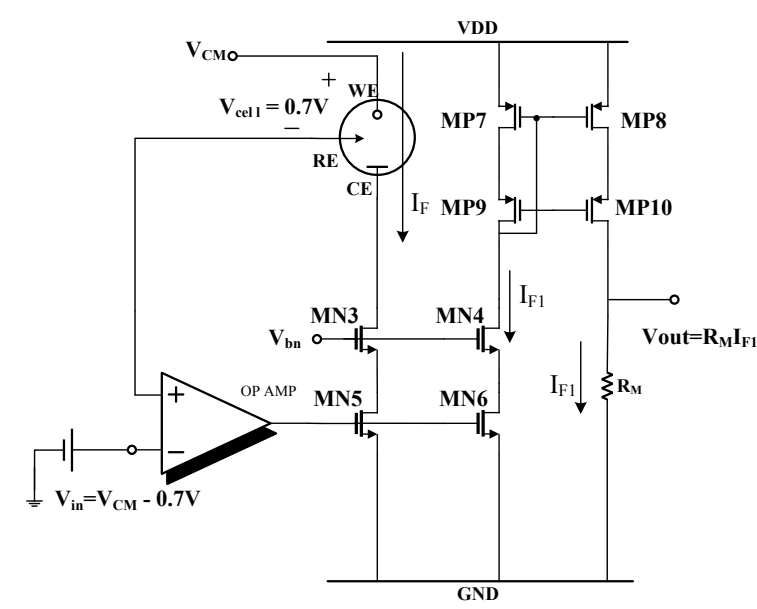

Fig. 6. Equivalent circuit of the proposed potentiostat for $\mathrm{H}_{2} \mathrm{O}_{2}$ - based glucose sensor.

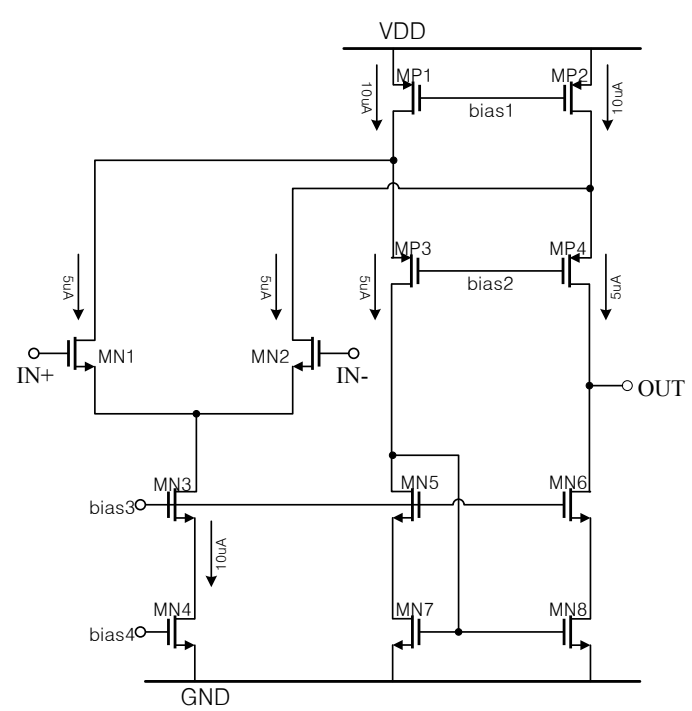

Fig. 7. Transistor level schematics of the operational amplifier.

PMOS MP5 and MP6 are off and the PMOS current mirror MP1MP4 is deactivated, but NMOS MN1 and MN2 are on and the NMOS current mirror MN3-MN6 and PMOS current mirror MP7-MP10 are activated. The reaction current $\mathrm{I}_{\mathrm{F}}$ that flows from WE to CE is copied to $R_{M}$ by cascode current mirrors, MN3-MN6 and MP7-MP10. The sensed current is determined by the voltage drop through $\mathrm{R}_{\mathrm{M}}$.

The operational amplifier was implemented by a folded cascode single stage amplifier that has only one pole to maximize the stability of the potential control loop, as shown in Fig. 7. The phase margin of this operational amplifier was approximately $82.8^{\circ}$ and the open loop gain was $67.8 \mathrm{~dB}$.

\section{MEASUREMENT RESULTS}

The proposed potentiostat circuit was verified by Cadence SPECTRE simulations using a $0.13 \mu \mathrm{m}$ thick oxide CMOS process. The layout was performed using Cadence Virtuso and verified using Mentor Calibre. Figure 8 shows the chip photography, which consists of a band gap reference, a comparator, an operational amplifier and an output stage. The area of the potentiostat 


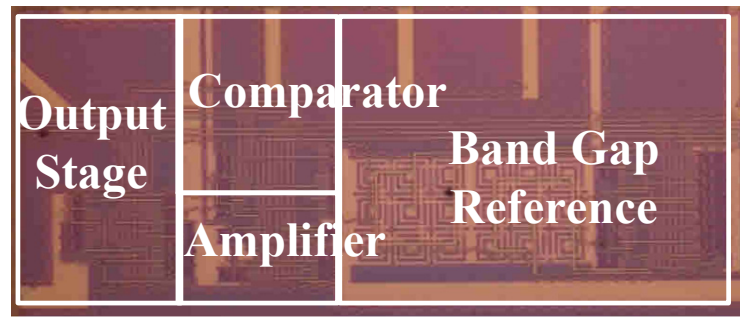

Fig. 8. Photography of the proposed potentiostat chip.

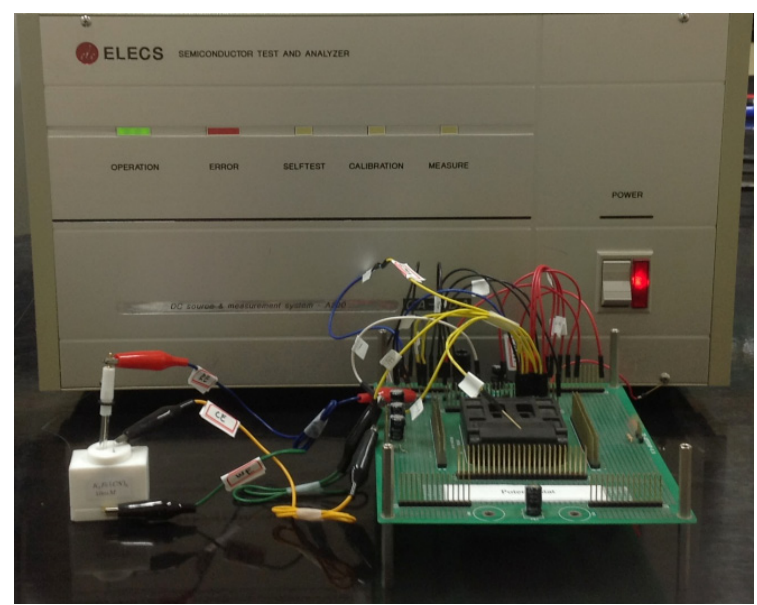

Fig. 9 . Photography of the measurement setup.

core was $360 \mu \mathrm{m} \times 100 \mu \mathrm{m}$

Figure 9 shows the photography of potentiostat measurement setup. This consists of the evaluation board, including a fabricated potentiostat chip, a parameter analyzer and an electrochemical cell of $\mathrm{K}_{3} \mathrm{Fe}(\mathrm{CN})_{6}$ solution.

First, we checked the performance of the fabricated chip with the electrical equivalent circuit of a three electrode electrochemical cell, instead of a $\mathrm{K}_{3} \mathrm{Fe}(\mathrm{CN})_{6}$ solution.

Figure 10 shows an electrical equivalent circuit of a three electrode electrochemical cell. In this model, the solution impedances are typically small and negligible. $R_{C}$ and $R_{W}$ represent the faradaic resistances, and $\mathrm{C}_{\mathrm{C}}$ and $\mathrm{C}_{\mathrm{W}}$ are the double layer capacitances associated with $\mathrm{CE}$ and WE, respectively.

These double layer capacitances and faradic resistances depend on the area of the electrodes and the solution concentration [8]. They can be expressed by

$$
C_{\mathrm{X}}=k_{\mathrm{C}} \cdot A_{\mathrm{X}}
$$

where $C_{X}$ is the capacitance of electrode $X, A_{X}$ is the area of the electrode $\mathrm{X}$, and $\mathrm{k}_{\mathrm{C}}$ is a constant with an approximate value of 0.36 $\mu \mathrm{F} / \mathrm{mm}^{2}[9] . \mathrm{R}_{\mathrm{W}}$ is defined as

$$
R_{\mathrm{W}}=V_{\text {cell }} / I_{\mathrm{F}}
$$

Note that $R_{W}$ must be recalculated based on the measured $I_{F}$ if $V_{\text {cell }}$ is changed. Normally $R_{W} \gg R_{C}$, because the area of the CE is larger than that of $\mathrm{WE}$, and typical values in electrode to sense blood glucose are $\mathrm{R}_{\mathrm{W}} \approx 1 \mathrm{M} \Omega, \mathrm{R}_{\mathrm{C}} \approx 10 \Omega$.

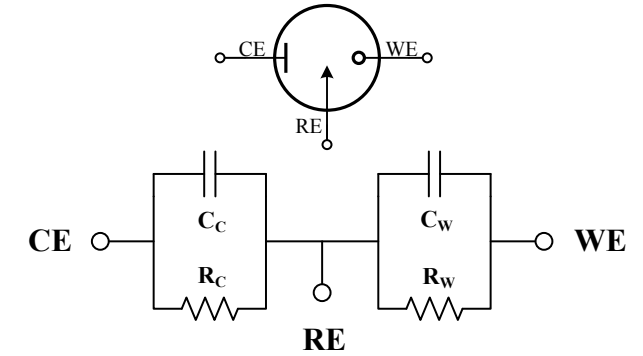

Fig. 10. Electrical-equivalent circuit of a three electrode electrochemical cell.

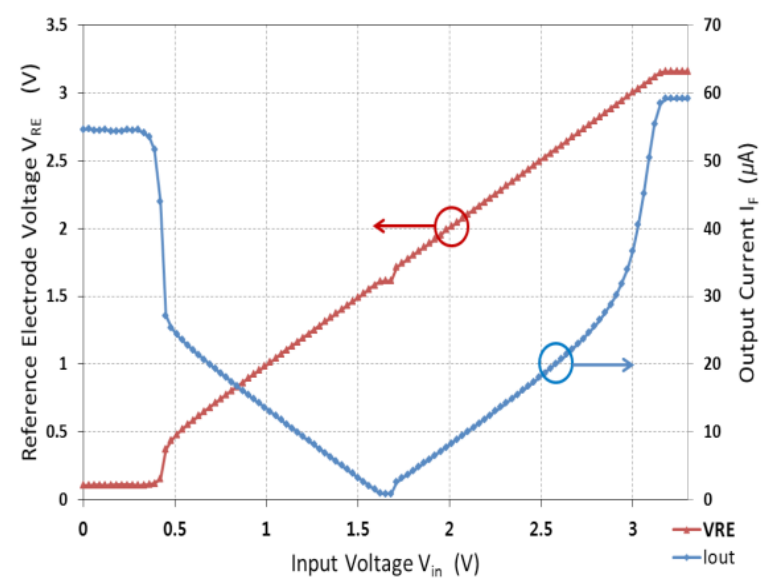

Fig. 11. Measured RE voltage and output current $I_{F}$ versus input voltage $V_{\text {in }}$.

Figure 11 shows the measurement results of the fabricated chip with the equivalent circuit of the three electrode cell. The supply voltage VDD and common-mode voltage $\mathrm{V}_{\mathrm{CM}}$ were $3.3 \mathrm{~V}$ and $1.65 \mathrm{~V}$, respectively. The RE voltage (left axis) followed the input voltage $\mathrm{V}_{\text {in }}$ from $0.5 \mathrm{~V}$ to $2.8 \mathrm{~V}$, which confirms that the negative feedback loop by the operational amplifier and MOSFETs MP1 and MN5 is operating well. In addition, the measured currents (right axis) show that both potentiostats for the negative cell voltage like the $\mathrm{O}_{2}$-based sensor $\left(\mathrm{V}_{\mathrm{in}}>\mathrm{V}_{\mathrm{CM}}\right)$ and positive cell voltage like the $\mathrm{H}_{2} \mathrm{O}_{2}$-based sensor $\left(\mathrm{V}_{\text {in }}<\mathrm{V}_{\mathrm{CM}}\right)$, worked well. The ranges of dynamic input voltage of this potentiostat are from 0.5 $\mathrm{V}$ to $1.6 \mathrm{~V}$ for the $\mathrm{H}_{2} \mathrm{O}_{2}$ - based sensor and from $1.7 \mathrm{~V}$ to $2.6 \mathrm{~V}$ for the $\mathrm{O}_{2}$ - based sensor.

Note that the faradaic resistance $R_{W}$, which is a function of $V_{\text {cell }}$, was fixed in this measurement setup. Therefore, output current $\left(\mathrm{I}_{\mathrm{F}}\right)$ is proportional to the input voltage $\left(\mathrm{V}_{\mathrm{in}}\right.$.) i.e.

$$
I_{\mathrm{F}}=V_{\text {cell }} / R_{\mathrm{W}}=\left(V_{\mathrm{CM}^{-}} V_{\mathrm{in}}\right) / R_{\mathrm{W}}
$$

We checked the operation of the proposed circuit with $\mathrm{K}_{3} \mathrm{Fe}(\mathrm{CN})_{6}$ solution, instead of the glucose solution, because the oxidation and reduction occur quickly in $\mathrm{K}_{3} \mathrm{Fe}(\mathrm{CN})_{6}$ solution. In contrast, in glucose, electrons are transferred very slowly and oxidation/reduction occurs slowly. Therefore, $\mathrm{K}_{3} \mathrm{Fe}(\mathrm{CN})_{6}$ solution is often used to check the operation of a potentiostat.

Figure 12 is the cyclic voltammetry measurement of $10 \mathrm{mM}$ $\mathrm{K}_{3} \mathrm{Fe}(\mathrm{CN})_{6}$ solution using a fabricated potentiostat. The commercial electrodes, which consist of $\mathrm{WE}(\mathrm{Pt})$ and $\mathrm{RE}(\mathrm{Ag} / \mathrm{AgCl})$, 


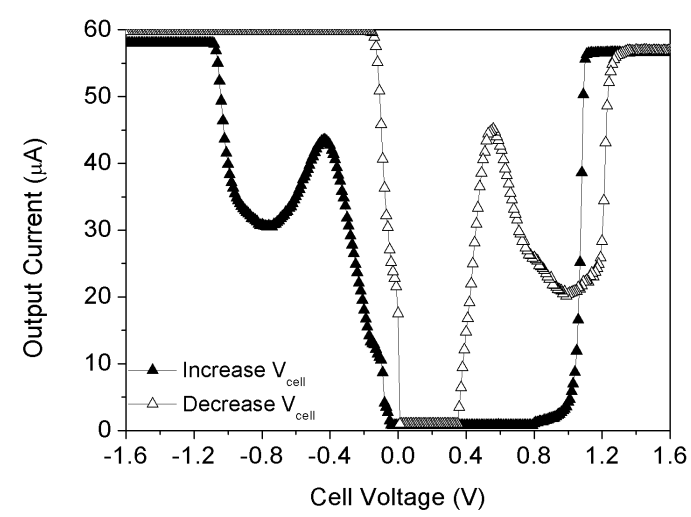

Fig. 12. Cyclic voltammetry measurement result of the $10 \mathrm{mM}$ $\mathrm{K}_{3} \mathrm{Fe}(\mathrm{CN})_{6}$ solution.

Table 1. Measurement summary of the proposed potentiostat.

\begin{tabular}{|c|c|c|}
\hline \multicolumn{2}{|c|}{ Process } & $0.13 \mu \mathrm{m}$ Thick Oxide CMOS \\
\hline \multicolumn{2}{|c|}{ Core Area } & $360 \mu \mathrm{m} \times 100 \mu \mathrm{m}$ \\
\hline \multicolumn{2}{|c|}{ Power current consumption } & $148 \mu \mathrm{A} @ \mathrm{VDD}=3.3 \mathrm{~V}$ \\
\hline \multirow{2}{*}{ Input range } & $\mathrm{H}_{2} \mathrm{O}_{2}$ based & $0.5 \mathrm{~V} \sim 1.60 \mathrm{~V} @ \mathrm{VDD}=3.3 \mathrm{~V}$ \\
\hline & $\mathrm{O}_{2}$ based & $1.70 \mathrm{~V} \sim 2.60 \mathrm{~V} @ \mathrm{VDD}=3.3 \mathrm{~V}$ \\
\hline \multicolumn{2}{|c|}{ Cell voltage in $10 \mathrm{~mole}_{3} \mathrm{Fe}(\mathrm{CN})_{6}$ solution } & $-0.43 \mathrm{~V},+0.56 \mathrm{~V}$ \\
\hline \multicolumn{2}{|c|}{ Range of operating supply voltage } & $2.4 \mathrm{~V} \sim 3.6 \mathrm{~V}$ \\
\hline
\end{tabular}

are used to sense the current reaction. When the cell voltage is increased from $-1.6 \mathrm{~V}$ to $+1.6 \mathrm{~V}$, the maximum sensing current occurs at $\mathrm{V}_{\text {cell }}=-0.43 \mathrm{~V}$. This means that this potentiostat drives the $\mathrm{O}_{2}$-based electrochemical glucose sensor. The maximum sensing current occurs at $\mathrm{V}_{\text {cell }}=+0.56 \mathrm{~V}$ when cell voltage decreases from $+1.6 \mathrm{~V}$ to $-1.6 \mathrm{~V}$. This means that this potentiostat drives the $\mathrm{H}_{2} \mathrm{O}_{2}-$ based electrochemical glucose sensor. These results show the proposed potentiostat can drive both $\mathrm{O}_{2}$ and $\mathrm{H}_{2} \mathrm{O}_{2}$-based electrochemical glucose sensors and detect the sensing current very well.

Table 1 summarizes the measurement results of the fabricated chip.

The performance of the proposed potentiostat is compared to that of other potentiostats in Table 2. The proposed potentiostat can drive both the $\mathrm{O}_{2}$ and $\mathrm{H}_{2} \mathrm{O}_{2}$-based electrochemical glucose sensors, but other potentiostats can drive only the $\mathrm{H}_{2} \mathrm{O}_{2}$-based electrochemical glucose sensors with positive power supply.

The core area of the proposed potentiostat is the smallest, even though this potentiostat can drive two kinds of electrochemical glucose sensors. The power consumption of the proposed potentiostat was lower than that of other potentiostats, except Ref [10], whose power consumption was a simulation result without chip fabrication. So, the power consumption of Ref [10] cannot be confirmed. From these comparative results, the proposed potentiostat is superior to conventional potentiostats.

\section{CONCLUSIONS}

This paper reported a new potentiostat circuit that can drive and measure the currents of both $\mathrm{O}_{2}$ - and $\mathrm{H}_{2} \mathrm{O}_{2}$ - based electrochemical glucose sensors with positive input voltage. In the proposed potentiostat, a one pole operational amplifier was used to obtain a stable feedback loop, which applies the cell potential, and cascode type current mirrors were used to achieve accurate copying of the reaction current. The proposed potentiostat was fabricated using a $0.13 \mu \mathrm{m}$ thick oxide CMOS process. The fabri-
Table 2. Performance comparison between the proposed potentiostat and other potentiostats.

\begin{tabular}{ccccc}
\hline & This work & Ref [10] & Ref [11] & Ref [12] \\
\hline \hline Technology & $0.13 \mu \mathrm{m}$ & $0.18 \mu \mathrm{m}$ & $0.5 \mu \mathrm{m}$ & $0.35 \mu \mathrm{m}$ \\
\hline Core Area & $0.036 \mathrm{~mm}^{2}$ & - & $0.087 \mathrm{~mm}^{2}$ & $0.16 \mathrm{~mm}^{2}$ \\
\hline $\begin{array}{c}\text { Power Con- } \\
\text { sumption }\end{array}$ & $489 \mu \mathrm{N}$ & $115 \mu \mathrm{N}$ & $19,000 \mu \mathrm{N}$ & $597 \mu \mathrm{N}$ \\
VDD & $3.3 \mathrm{~V}$ & $1.8 \mathrm{~V}$ & $5.0 \mathrm{~V}$ & $3.3 \mathrm{~V}$ \\
IDD & $148 \mu \mathrm{A}$ & $64 \mu \mathrm{A}$ & $3.8 \mu \mathrm{A}$ & $181 \mu \mathrm{A}$ \\
\hline $\begin{array}{c}\text { Detect sensor } \\
\text { type }\end{array}$ & $\mathrm{O}_{2}$ based & & & \\
\hline
\end{tabular}

cated potentiostat was verified using the electrical-equivalent circuit of the electrochemical cell. Test results showed that the current of the $\mathrm{O}_{2}$-based sensor can be measured with the input voltage from $1.7 \mathrm{~V}$ to $2.6 \mathrm{~V}$ and that of the $\mathrm{H}_{2} \mathrm{O}_{2}$ - based sensor could be measured with input voltage from $0.5 \mathrm{~V}$ to $1.6 \mathrm{~V}$ at a supply voltage of $3.3 \mathrm{~V}$. The operation of the fabricated potentiostat was also confirmed using a $\mathrm{K}_{3} \mathrm{Fe}(\mathrm{CN})_{6}$ solution. These results show the proposed chip was a good potentiostat that can drive both $\mathrm{O}_{2}$-based and $\mathrm{H}_{2} \mathrm{O}_{2}$ - based glucose sensors.

\section{ACKNOWLEDGMENTS}

This work was supported by the research grant of the Chungbuk National University in 2011.

\section{REFERENCES}

[1] E. Wilkins and P. Atanasov, Medical Engineering and Physics, 18(4), 273 (1996) [DOI: http://dx.doi.org/10.1016/13504533(95) 00046-1].

[2] S. M. Martin, F. H. Gebara, T. D. Strong and R. B. Brown, IEEE Proc. Int. Symposium on Circuits \& Systems, 892 (2004) [DOI: http://dx.doi.org/10.1109/ISCAS.2004.1329148].

[3] M. M. Ahmadi and G. A. Jullien, IEEE Transactions on Circuits and Systems I , 56(7), 1339 ( 2009) [DOI: http://dx.doi. org/10.1109/TCSI.2008.2005927].

[4] H. S. Narula and J. G. Harris, IEEE Sensors Journal, 6(2), 239 (2006) [DOI: http://dx.doi.org/10.1109/JSEN.2006.870142].

[5] S. Ayers, K. D. Gillis, M. Lindau and B. A. Minch, IEEE Trans.Circuits Syst. I, Reg. Papers, 54(4), 736 (2007) [DOI: http://dx.doi. org/10.1109/TCSI.2006.888777].

[6] S. M. R. Hasan, IEEE Sensors Journal, 7(5), 814 ( 2007) [DOI: http://dx.doi.org/10.1109/JSEN.2007.893236].

[7] R. Doelling, http://www.bank- ic.de/encms/downloads/potstae2.pdf., (2000).

[8] S. M. Martin, F. H. Gebara, T. D. Strong and R. B. Brown, IEEE Sensors Journal, 9(2), 135 (2009) [DOI: http://dx.doi. org/10.1109/JSEN.2008.2011085].

[9] S. Martin, Ph.D. Thesis, p.37, Univ. of Michigan, Ann Arbor, MI (2005).

[10] M. Duwe and T. Chen, Proc. IEEE Int. Symposium on Circuits \& Systems, 1, (2011) [DOI: http://dx.doi.org/10.1109/MWSCAS.2011.6026521].

[11] S. Hwang and S. Sonkusale, IEEE Sensors Journal, 10(4), 820, (2010) [DOI: http://dx.doi.org/10.1109/JSEN.2009.2035098].

[12] W. Y. Chung, A.C. Paglinawan, Y. H. Wang and T. T. Kuo, Proc. IEEE Conference on Electron Devices and Solid State Circuits, 1087, (2007) [DOI: http://dx.doi.org/10.1109/ EDSSC.2007.4450317]. 